\title{
State of Fisheries in Lake Qarun, Egypt: Review Article
}

\author{
Kariman A. Sh. Shalloof \\ Fisheries Biology Lab., Fisheries Division, NIOF, Egypt
}

Received: December 12, 2019

Accepted: February 20, 2020

\begin{abstract}
This article aims to review the available studies concerning fisheries status of Lake Qarun to suggest an effective strategy for improving its annual total fish catch. Data were collected from the available Publications from GAFRD (General Authority for Fish Resources Development), Central Agency for Public Mobilization and Statistics (CAPMAS), and data collected from reports funded by World Fish Center and FAO were used as data sources of this article. In addition to published papers and reports. Also, from extended visits to Lake Qarun. This article introduces information about study area, environment of Lake Qarun, fishing boats and methods, total fish production, species composition and different biological studies that carried out on Lake Qarun from 1935 till 2019. Recommendations for proper management of this selected sector were recorded in the present study.
\end{abstract}

Keywords: Lake Qarun, Fisheries, fishing boats, environment, management.

\section{Introduction}

Lake Qarun is the only enclosed saline lake in Egypt and it represents one of the important sectors in the Egyptian fisheries, for both significant total catch and a large number of economically important species (Shehata et al., 2017). It has unique ecosystem that attracts attention of several authors to study, beside it has historic and scientific importance.

Since the beginning of $20^{\text {th }}$ century, several investigations have been done concerning Lake Qarun fisheries including those of Wimpenny and Faouzi (1935), Faouzi (1936), Wimpenny (1936), El-Zarka (1963), El-Zarka and El-Sadafy (1967), Boraey (1974), AbdelMalek (1980; 1982), Ishak et al. (1982), Sweilum (1989), Mosaad (1990), Gabr (1998), ElShabrawy and Fishar (1999) and El-Serafy et al. (2014). However, these studies are still scarce and fragmentary (Konsowa, 2006). Therefore this study aims to review the available studies concerning fisheries status of this lake to help in suggesting an effective strategy to improve its total fish production.

\section{Data sources}

The author used publications from GAFRD (General Authority for Fish Resources Development), Central Agency for Public Mobilization and Statistics (CAPMAS), and data collected from reports funded by World Fish Center and FAO. In addition to published papers and reports. Also, there have been extended visits to Lake Qarun.

\section{Review \\ Study Area:}

Lake Qarun is located in the western desert part of Fayoum depression Lake and it is centered around $29^{\circ} 30^{\circ} \mathrm{N}, 30^{\circ} 40^{\circ} \mathrm{E}$ (Fig.1). Its length is about $40 \mathrm{~km}$ from east to west, and the 


\section{Kariman A. Sh. Shalloof}

breadth at its widest point is about $6.7 \mathrm{~km}$. Its surface area is about $243 \mathrm{~km} 2$ and its water volume is about 924 million $\mathrm{m} 3$ at $43 \mathrm{~m}$ below sea level (Anonymous, 1995). The deepest point $(\sim 8.3 \mathrm{~m})$ is located northwest of the island. The lake has no connection to the sea, being located $320 \mathrm{~km}$ south of the Mediterranean coast of Egypt, and is sustained directly by the Nile River through the Bahr Yussef canal. The lake and surrounding area is a protected area and has been designated as a Ramsar site since 2012. It is bordered from its northern side by the desert and by cultivated land from its south and southeastern side (Abdel-Satar et al., 2010).

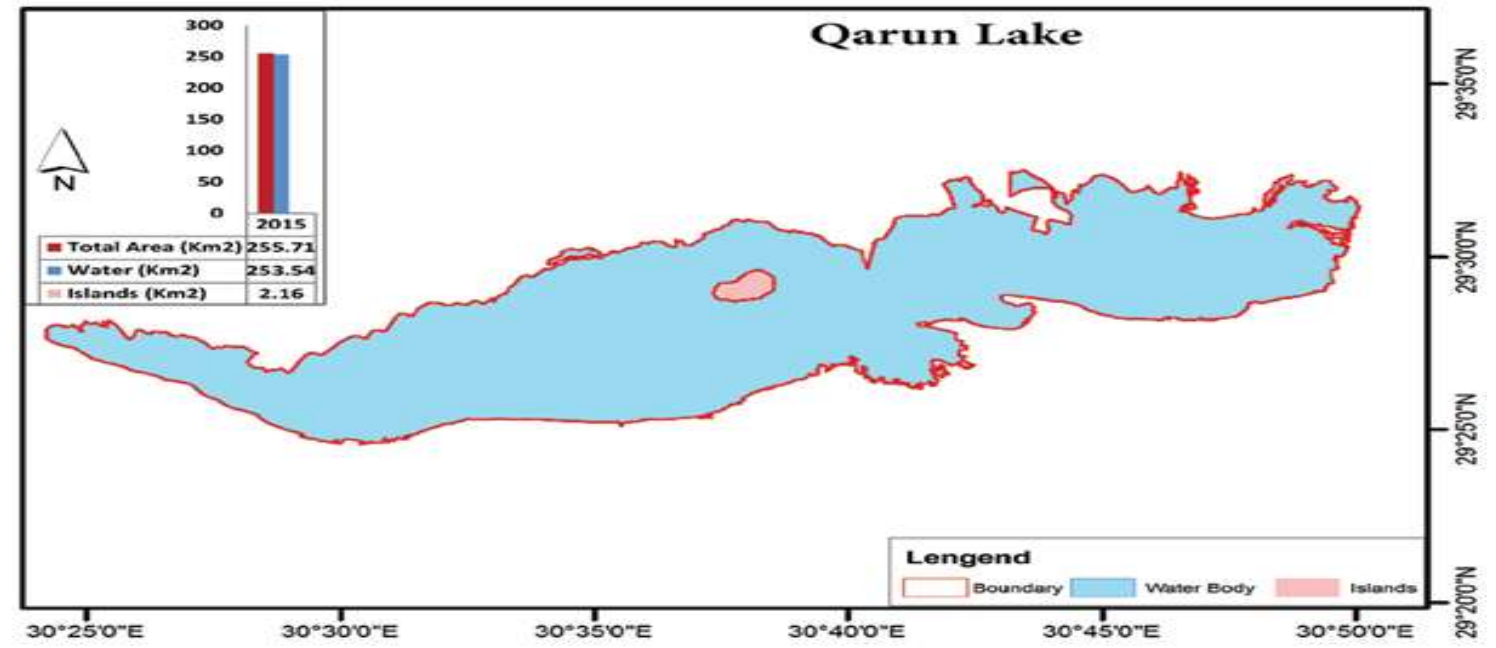

Fig. 1: Map show Qarun Lake; location, total area and water surface (After GAFRD, 2015).

\section{Environment of Lake Qarun:}

Lake Qarun is immense freshwater palaeo-lake, occupies part of the basin of ancient Lake Mories that persisted until the mid Holocene (Hassan, 1986). Lake Qarun now has the salinity of seawater (Aleem, 1985). Gradual increasing salinity has accelerated since $\sim 1900$ s (Ball, 1939), reached 32-36 g/L in 1975/76 (Boraey, 1980), and caused a profound effect on lake fauna and flora.

Lake Qarun still suffers nowadays from several environmental problems. The progressive increase of its salinity was considered as the most serious problem which affects the different life aspects in the lake. Also, the aggravation of eutrophication of the lake's water, that caused by the nutrient carriage from the agricultural drainage water (Sabae and Ali, 2004). These conditions led to change in the biodiversity of the different biota (Mageed, 2005).

Several drains (El-Bats, El-Wadi and El-Berkah Drains) of El-Fayoum irrigation systems terminate and pour highly amounts of fresh or brackish water into Lake Qarun. Such water is loaded with wastes, salts and nutrients that may accumulate and contaminate the aquatic environment (Hassan, 2002; Ghanem, 2006 \& 2011 and Khalaf-Allah, 2014).

Al-Afify et al. (2019) reported that, municipal and agricultural sewage wastes discharged into Lake Qarun causes serious problem of its water quality. They added that the water quality index (WQI) values indicated that the lake water is poor for irrigation and aquatic life guidelines.

As a result of increasing land reclamation in Fayoum Province over the past decade, it was necessary to find another reservoir to receive quantities of agricultural wastewater drainage 


\section{State of Fisheries in Lake Qarun, Egypt: Review Article}

exceeding the capacity of the lake. This was achieved by transferring the surplus drainage to Wadi El -Rayan Depression, where two man-made lakes were created at two different levels. The first lake has nearly half the area of the second lake, and they are joined by a connecting shallow channel (Zahran, 1973; El-Shabrawy, 1999). The first lake of Wadi El-Rayan receives frequent effluent of wastewater from the Wadi Drain.

Concerning salinity of Lake Qrun, it was increased throughout the 20th century (Fig. 2), being around 14\% in the early 1900s (Ball, 1939). Mean salinity reached an average $38 \%$ in the 1980s but, since then, has stabilized. Seasonally, soluble salts in the lake increase during summer and this is can be attributed to evaporation and changes in the inflow regime. Being located in an arid area with intensive evaporation $\left(\sim 7 \mathrm{~mm} \mathrm{~h}^{-1}\right)$, freshwater input does not compensate for seasonal evaporation and salinity increases. The salinity of the lake is not homogenous, being lower near the mouth of the inflows that drain the lakes southern landscape (Fathi and Flower, 2005).

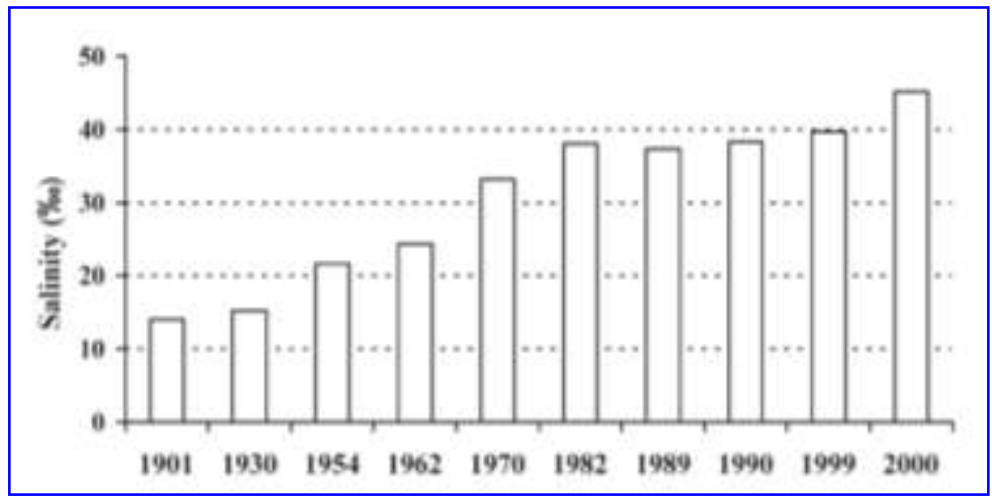

Fig. 2. Changes in salinity in Lake Qarun during the period 1901-2000 (Soliman, 1990; Anonymous, 1995; El-Sayed and Guindy, 1999; Fathi and Flower, 2005).

\section{Fishing boats and methods:}

About 615 woody non-motorized fishing boats (Fig. 3) were operated in the lake during 2010- 2011. Four fishermen were working on each boat. The fishing gears used in the lake namely; 1-Trammel nets with four types differed in their dimensions, mesh sizes and mainly targeting Mugil cephalus, Tilapia zillii, Solea spp. and Liza spp. 2- Seine nets with three types and targeting M. cephalus, anchovy and shrimp. 3- Others fishing methods (Fishing aggregation system, traps and hooks) targeting mainly T. zillii (El- Serafy et al., 2014).
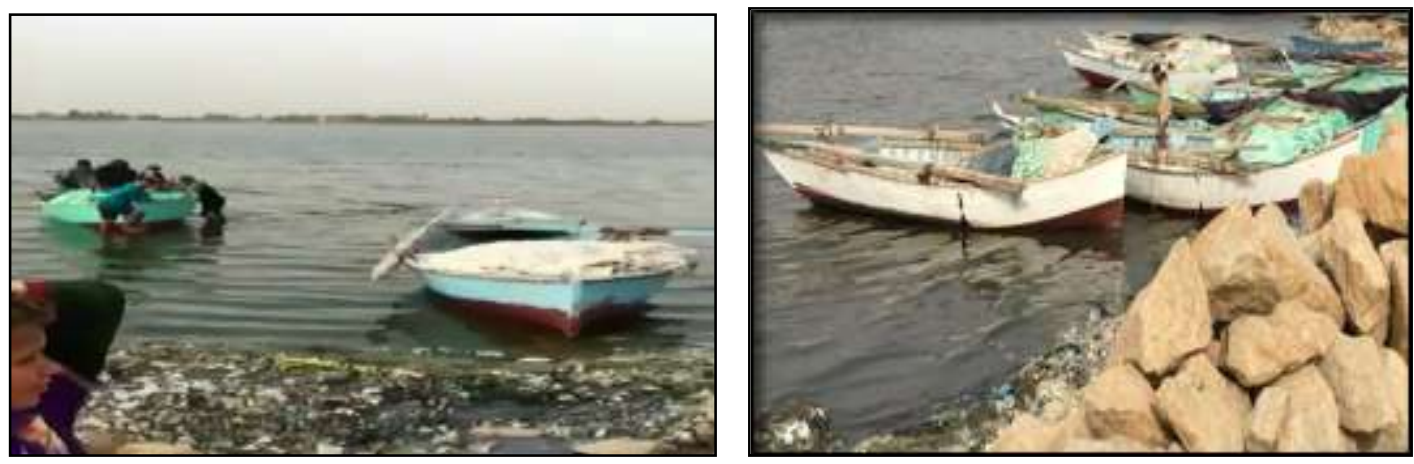

Fig. (3): Photos showing Lake Qarun fishing boats. 
Krzebietke et al., (2016) reported that, the main fishing equipment used in the lake was trammel nets, beach seines, hand lines and traps. There were four types of trammel nets which differed in their design, characters, dimensions and mesh sizes according to their target species. The first trammel net (Ghazl Bolti) mainly targeted tilapians, particularly Tilapia zillii. This worked effectively in the East and Middle sub-areas of the lake. The second trammel net (Ghazl Bory), which targeted Mugil cephalus worked mainly in the northern part of the lake and deeper water. The third trammel net (Ghazl Mossa) was set mainly on the bottom to catch sole fish, e.g. Solea solea and S. aegyptiaca. It operated mainly in the middle and western parts of the lake. The fourth trammel net (Ghazl Fahhar) targeted mullet fish species other than M. cephalus, such as Liza ramada, L. aurata and L. saliens. It was mainly active in the Middle sub-area. Beach seines with two main types, Gorafet Bory and Gorafet Zardina, were also set in the lake. Gorafet Bory was targeted mainly by $M$. cephalus and it operated in the northern beach of the lake, while Gorafet Zardina was present mostly in the southern beach and targeted anchovy. Other fishing gears, handlines and traps were mostly targeted by $T$. zillii in the eastern and middle sub-areas

\section{Total fish production of Lake Qarun:}

The commercial total annual catch decreased from 4000 tonnes during 1920 to an average of 1- 2 thousand tonnes in subsequent years (El-Serafy et al., 2014).

To compensate the drop in fish production, some marine fishes were introduced and transplanted to the lake including Mugil spp. , Solea spp.,Sparus aurata, Dicentrarchus labrax and shrimps. Liza saliens, Solea spp. and shrimps were succeeded to acclimatize and spawn in the lake (El-Serafy et al., 2014). On the other hand, some species like, Atherina spp. were accidentally introduced as fry mixed together with mullet fry (Anonymous, 2007).

For the period 2002-2011, the average annual total fish catch was about 3000 tonnes (GAFRD, 2012), represented mainly by four fish groups; tilapias, mullets, soles and shrimps. According to GAFRD fish statistics (2002-2011), catch per unit effort (CPUE) has an average of $29.286 \mathrm{~kg} / \mathrm{boat} / \mathrm{day}$. The total annual fish landing for different species from Lake Qarun during this period is shown in Figure (3).

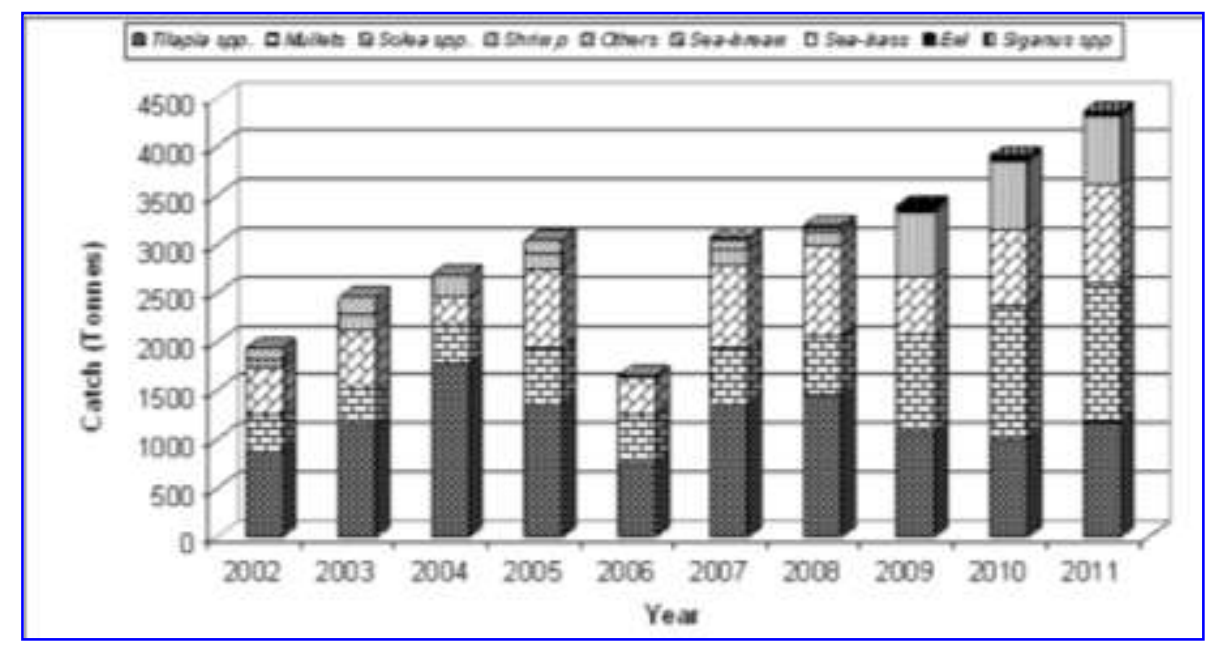

Fig. 3. Total annual fish landings for different species from Lake Qarun according to GAFRD for the period (2002-2011) (After El-Serafy et al., 2014). 


\section{State of Fisheries in Lake Qarun, Egypt: Review Article}

The commercial catch in Qarun Lake dropped from around 4000 tons per year during last 5 years to be about less than 1000 tons in 2016 (GAFRD, 2017) ( Fig.4).

Recently, Qarun Lake undergo parasitic infection (Isopoda), on its fishery production which has a bad impact on the lake production, fish quality and fishermen community.

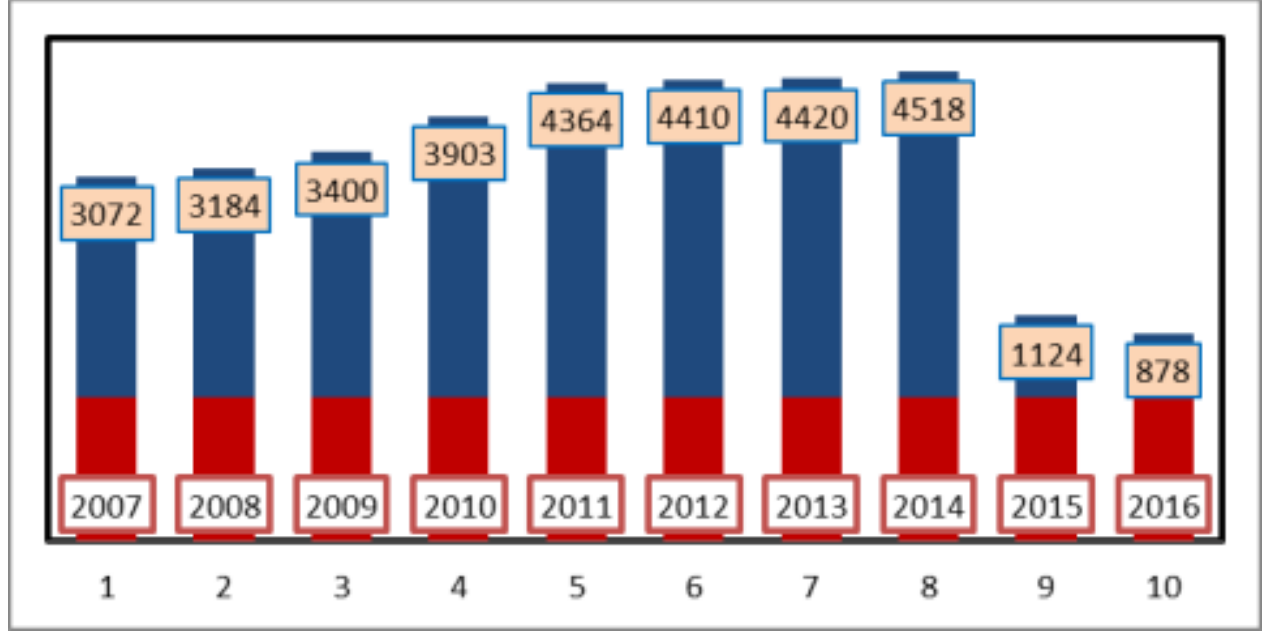

Fig. (4): Development of Qarun Lake fisheries during the period from 2007 to 2016 (GAFRD, 2017).

Poor fish production in Lake Qarun is a direct result for implementation of irrational and unevaluated policies such as introducing of some species to the lake (El-Far, 2014). Moreover, some invasive species like isopods (Nerocila orbigyni) and jelly-fishes are affected the fish production and fish quality in the recent three years (Anonymous, 2015 and El-Shabrawy \& Dumont, 2016).

All fresh-water species with the exception of Tilapia spp. and Anguilla spp. gradually disappeared from the lake depending on their tolerance to salinity (El-Zarka, 1961\&1963).

Abdel- Malek et al. (1990) revealed that the main factors accounted for the decline of fisheries in Lake Qarun is related to dryness of the coastal area (area of spawning to most fishes) due to lowering of water level, during the period 1970-1977. Also, this decline was due to introducing of some predatory marine fish species and increasing natural mortality due to pollution and to increased water salinity.

\section{Species Composition:}

El-Zarka (1961) mentioned that Tilapia zillii and Solea vulgaris were considered as the main fishes in Qarun Lake as they compose more than 65\% of the annual total catch of the lake, beside they spawn in it. On the other hand, Mugil species, Angulla vulgaris, Sparus auratus and shrimp are transported as fries from their spawning regions in the Mediterranean Sea to the lake. El- Zarka (1963 a \&b) studied the acclimatization of both Solea vulgaris (Linn.) and Mugil saliens (Larr.) in Lake Qarun. El- Zarka and El- Sedfy (1970) studied the biology and fishery of Mugil saliens (the catch, age \& growth composition, size distribution and reproduction) in Lake Qarun. Al-Kholy and Abdel-Malek (1971) studied food and feeding habits of some Egyptian fishes in Lake Qarun. The later authors studied T. zillii (Gerv.) at different localities. AbdelMalek (1972 a \&b) studied food and feeding habits of T. zillii (Gerv.) in relation to different length group and sex. Ezzat et al. (1979) studied biometric variation in Solea vulgaris acclimatized in Lake Qarun, Upper Egypt. They investigate the morphology of these fishes and 
made measurements and compare with those of fish caught in the Mediterranean. Ishak et al. (1982) studied length and age composition of mullets in Lake Qarun, they found that the growth in length and weight of Mugil cephalus were better in the lake than in other coastal area of Egypt. They recommended that studies should continue to improve survival of transplanted mullet fry into the lake.

Mosaad (1990) studied the length- weight and condition factor (K) of the most common fishes in Lake Qarun (Mugil capito, Mugil cephalus, Mugil saliens, Solea vulgaris and Tilapia zillii). Ibrahim (1993) studied the length-weight relationship, age- length Kay, age composition, Gonado- somatic index, fecundity, length frequency distribution and food items of Metapenaeus spp. Solea spp, Liza spp. and Tilapia spp. in the lake. Falts (1995) studied the population dynamics of Tilapia zillii in Lake Qarun during 1991 to samples taken from the trammel net catch. Saleh et al. (1995) computed the annual total catch, annual catch of Tilapia zillii (as pelagic fish) and Solea vulgaris (as bottom fish).

Shalloof (2009) studied fisheries biology of T. zillii and Solea vulgaris in Lake Qarun. She concluded that decline in the value of condition factor $(\mathrm{K})$ and disappearances of older age groups of both two studied species reflect the drastic condition of Lake Qarun which had a profound effect on its fauna and flora.

El-Serafy et al., (2014) studied Qarun Lake fisheries; Fishing gears, Species composition and Catch per unit effort. They concluded that the species composition for the mostly used gear in Lake Qarun as follow Mugil cephalus, Liza ramada and Liza saliens,Solea spp., Tilapia zillii, Gobius niger, Dicentrarchus labrax and Engraulis encrasicolus and shrimps.

Table (1): Scientific and local names of different species in Lake Qarun , Egypt

\begin{tabular}{|l|c|}
\hline \multicolumn{1}{|c|}{ Scientific name } & Local name \\
\hline Mugil cephalus (Linnaeus,1758) & Bouri \\
\hline Liza ramada(Risso, 1826) & Tobara \\
\hline Solea spp. & Moussa \\
\hline Dicentrarchus labrax (Linnaeus,1758) & Qarous \\
\hline Anguilla Anguilla(Linnaeus,1758) & Hannash \\
\hline Engraulis encrasicolus(Linnaeus,1758) & Bolti akhdar \\
\hline Tilapia zillii(Gervais, 1848) & Bolti sultani( nily) \\
\hline Oreochromis niloticus (Linnaeus,1758) & Bolti Ain Salem \\
\hline Sarotherodon galilaeus(Linnaeus,1758) & Gambari abiad) \\
\hline Metapenaeus stebbingi ( Nobili, 1904) & Shamoth \\
\hline Bagrus spp . & Keshr Bayad \\
\hline Lates niloticus(Linnaeus,1758) & \\
\hline
\end{tabular}

\section{Conclusion:}

From the previous survey of literatures, it is possible to conclude that Qarun Lake fish production face many problems like the environmental challenges due to rising the salinity, and polluted water drains (without treatment), and uncontrolled fishing practice. Recently, Qarun Lake undergo parasitic infection (Isopoda), on its fishery production which has a bad impact on the lake production, fish quality and fishermen community. 


\section{State of Fisheries in Lake Qarun, Egypt: Review Article}

\section{Recommendations:}

1- Treatment of sewage before discharged into the lake (since the commercial catch in Qarun Lake dropped to be about less than 1000 tons in 2016.

2- Supply depression with large quantities of healthy fry especially from El- Bardawil Lake, since different studies recorded that this lake less polluted comparing with other Egyptian lakes.

3- Using of legal fishing methods.

4- Reduce the salinity of the lake by supplying the lake with a larger amount of water.

5- Use of biological control against isopod parasite after further research by specialists.

6- More research into biological and environmental studies of Isopoda parasite to learn how to resist it.

7- The establishment of fish ponds where fish fry is placed for a specific period of time before being transferred to Lake Qarun and Wadi Al Rayyan to ensure that they are free from any parasites or unwanted fish species.

8- Pay attention to the fishermen community and find ways to compensate them for staying in the lake.

9- The competent authorities shall work together to develop solutions for the development of the lake.

\section{References}

Abdel-Malek S.A. (1972a). Food and feeding habits of some Egyptian fishes in Lake Qarun Part 1-Tilapia zillii (Gerv.). A: according to different length groups. Bull. Nat. Oceanogr.\& Fish., 2: 203-213.

Abdel-Malek S.A. (1972b). Food and feeding habits of some Egyptian fishes in Lake Qarun Part 1- Tilapia zillii (Gerv.). B: according to different sexes. Bull. Nat. Oceanogr. \& Fish., 2: 239-259.

Abdel-Malek, S.A. (1980). Food and feeding relationship between fishes in Lake Qarun. J. Icht., 20 (2): 272-276.

Abdel-Malek, S.A. (1982). Biological productivity of Lake Qarun. J. Icht., 21 (6): 990-1000.

Abdel-Malek, S.A.; Khalil, M.T. and Ali, A.H. (1990). Studies in some ecological factors affecting the fish production of Lake Qarun. Bull. Nat. Oceanogr. \& Fish., A.R.E., 16 (1): 41-48.

Abdel-Satar, A.M.; Goher, M. E. and Sayed, M. F. (2010). Recent Environmental changes in water and sediment quality of Lake Qarun. Egypt. J. Fish. Aquat. Sci., 5 (2): 56- 69.

Al-Afify, A. D.; Tahoon, U.M. and Abdo, M.H. (2019). Water Quality Index and Microbial Assessment of Lake Qarun, El-Batts and El-Wadi Drains, Fayoum Province, Egypt. Egypt. J. Aquat. Biology \& Fish., 23(1): $341-357$.

Aleem, A. A. (1985). A taxonomic and paleoecological investigation of the diatom flora of the extinct El-Fayoum Lake (Upper Egypt). I- Systematic part. Bull. Fac. Sci. Alex. Univ (Egypt) 2: 99-138.

Al-Kholy, A.A. and Abdel_Malek S. A. (1971). Food and feeding habits of some Egyptian fishes in Lake Qarun. Part 1.Tilapia zillii (Gerv.). A: according to different localities.Bull. Nat. of Oceanogr. \& fish., A. R. E., 2: 187- 201.

Anonymous (1995). Lake Qarun and its development in the modern era, and its ecological development. First Scientific Forum. Organized by the Egyptian Company for Salts and Minerals. Shakshouk, El-Fayoum, Egypt, 174 pp. (in Arabic) 


\section{Kariman A. Sh. Shalloof}

Anonymous (2007).Trends of biological parameters of Lake Qarun ecosystem. Nat.Inst. Oceano.Fish.(NIOF), Final report, submitted to CDM Company Internat.INC.

Anonymous (2015). The impact of environmental pollutions on some physiological and biological parameters of the fishes of Qarun and Wadi El-Rayan lakes, (NIOF), the final report submitted to STDF.

Ball, J. (1939). Geography of Egypt. Buluq Press, Cairo, 221pp.

Boraey, F.A. (1974). Biological study of the family Mugilidae (grey mullets) in Lake Qarun. Ph.D. Thesis Fac. Sci. Ain Shams Univ. 296 pp.

Boraey, F.A.( 1980). Studies on the changes of some ecological factors affecting fish life in Lake Qarun. Faiyum, Egypt. Water Supply and Management, 4: 99-102.

El-Far, A.M. (2014). Assessement of Qarun Lake fisheries with special reference to fishery biology of Solea spp. Ph. D. thesis, Fac. Sc. Benha Unvi. 210 P.

El-Sayed, E. and K. H. A. Guindy (1999). Hydrochemical investigation of El-Fayoum locality with special references to the sulphate enrichment phenomenon in Lake Qarun. Mans. Sci. Bull. Mansoura University (Egypt), 26: 1-21

El-Serafy, S.S.; El-Haweet, A.E. A., El-Ganiny, A.A. and El-Far, A.M. (2014). Qarun Lake fisheries; Fishing gears, Species composition and Catch per unit effort. Egypt. J. Aquat. Biol. \& Fish., 18(2): 39- 49.

El-Shabrawy, G. and Dumont, H.J. (2016). First record of a ctenophore in lakes: the comb-jelly Mnemiopsis leidyi, A. Agassiz, 1865 invades the Fayum, Egypt. BioInvasions Records, 5 (1): 21-24.

El-Shabrawy, G.M. (1999). Monthly variations and succession of Rotifera in Wadi El-Rayan area in relation to some physical and chemical conditions. Egypt. J. Aquat. Biol. Fish., 3(3): 217-243.

El-Shabrawy, G. M. and R. M. Fishar (1999). Zooplankton consumption and feeding habits of mullet fry in Lake Qarun Egypt .The role of science in the development of Egypt society and environment 23-24 Oct: 175-186.

El-Zarka, S. E. (1961).Tilapia fisheries investigations in Egyptian lakes. II: A biological study of the fisheries of Tilapia zillii in Lake Qarun. Notes and memoirs No. 66: 44 pp.

El-Zarka, S. (1963). Acclimatization of M. saliens Risso in Lake Qarun. U. A. R. Proc. Fish. Counc. Medit., 7: 337-346.

El-Zarka, S.E. (1963 a). Acclimatization of Solea vulgaris (L.) in Lake Qarun, Egypt. J. Cons. Perm. Int. Explor. Mer., 28(1): 126-136.

El-Zarka, S. E. (1963 b). Acclimatization of Mugil salines (Risso.) in Lake Qarun, Egypt. United Arab Republic. Proc.Gen.Fish.Coun.Medit., 7: 337- 346.

El-Zarka, S. and H. El-Sedafy (1970). The biology and fishery of Mugil saliens (Risso.) in Lake Qarun U. A. R. Bull.Nat. Inst. Oceangr and Fish., 1: 1-26.

Ezzat, A.A.; Hashem, M. T. and El- Gharabawy, M. M. (1979). Biometric variation in Solea vulgaris acclimatized in Lake Quarun, Upper Egypt.J.Fish Biol., 14: 39- 46.

Faltas, S.N. (1995). Population dynamic of Tilapia zillii (Gerv.) in Lake Qarun, Egypt. Bull. Nat. of Oceanogr. \& fish., A. R. E., Vol 21 (2): 517-527.

Fathi, A.A. and Flower, R.G. (2005). Water quality and phytoplankton communities in Lake Qarun (Egypt). Aquat. Sci., 67: 350-362

Foauzi, H. (1936). Successful stocking of Lake Qarun with mullets. Int. Rev. Gesamten. Hydrobiol. Hydrogr. 33: 343-439. 


\section{State of Fisheries in Lake Qarun, Egypt: Review Article}

Fott, B. (1972). Das Phytoplankton des Sûsswassers. 6-Chlorophyceae, Ordnung. Tetrasporales. Stuttgart: $116 \mathrm{pp}$

Gabr, M. H. (1998). Biological studies on Liza saliens in Lake Qarun, ElFayoum, Egypt. M. Sc. Thesis Fac. Sci. Banha Univ. 290 pp.

GAFRD, General Authority for Fish Resources Development (2002- 2011).Annual fishery statistics report. Ministry of Agriculture Publications, Cairo, Egypt.

GAFRD, General Authority for Fish Resources Development (2012).Annual fishery statistics report. Ministry of Agriculture Publications, Cairo, Egypt.

GAFRD, General Authority for Fish Resources Development (2015).Annual fishery statistics report. Ministry of Agriculture Publications, Cairo, Egypt.

GAFRD, General Authority for Fish Resources Development (2017).Annual fishery statistics report. Ministry of Agriculture Publications, Cairo, Egypt.

Ghanem, M.H.M. (2006). Ecological, physiological and histopathological studies on the grey mullet, Mugil cephalus, at different Egyptian lakes. M.Sc. Thesis, Zool. Dep. Fac. Sci., Al- Azhar Univeristy, Egypt, Pp: 456

Ghanem, M.H.M. (2011): Seasonal variations of total proteins, lipids and carbohydrates in cultivated, brackish and salt water fish with special references to their nutrient values. $\mathrm{Ph}$. D. Thesis, Zool. Dep.Fac. Sci., Al-Azhar Univeristy, Egypt, Pp: 396.

Hassan, A.M. (2002). Ecological and biological studies on zooplankton in Lake Qarun, Egypt. Ph. D. Thesis, Zool. Dep. Fac. Sci., Al-Azhar Univeristy, Egypt, Pp: 309.

Hassan, F.A. (1986). Holocene lakes and prehistoric settlements of the western Faiyum. J. Arch. Sci., 13: 483-501.

Ibrahim, E.A. (1993). Lake Ecosystem studies. Lake Qarun, Egypt. Principle investigation. Tech. Rep.: 225pp.

Ishak, M.M; Abdel- Malek, S.A. and Shafik, M.M. (1982). Development of Mullet fisheries (Mugilidae) in Lake Qarun, Egypt. Aquaculture, 27: 251-260.

Khalaf-Allah, H.M.M. (2014).Seasonal distribution and abundance of small fish in the south coast of Lake Qarun, Egypt, World J. Fish Marine Sci., 6 (1): 109- 118.

Konsowa, A.H. (2006). Food habits of most common fishes inhabiting Lake Qarun (El-Fayoum, Egypt). Egypt. J. Exp. Biol. (Zool.), 2: 47- 53.

Krzebietke, A. N.; Hussian, A.M.; Abd El-Monem, A.M. and El-Far, A.M. (2016). Interrelations between phytoplankton and fish in the nutrient rich shallow Lake Qarun, Egypt. Oceanological and Hydrobiological Studies, 44: 539- 553.

Mageed, A.A.A. (2005).Effect of some environmental factors on the biodiversity of holozooplankton community in Lake Qarun, Egypt.Egyp. J. Aqu. Res., 31:230-249.

Mosaad, H. (1990). Biological studies on five fish species from Lake Qarun, Egypt. Proc. Zool. Soc. A. R. Egypt, 21: 331-344

Sabae, S.Z. and M.H. Ali. (2004). Distribution of nitrogen cycle bacteria in relation to physicochemical conditions of a closed saline lake (Lake Qarun, Egypt). J. Egypt. Acad. Soc. Environ.Develop., (D-Environmental Studies), 5 (1): 145-167.

Saleh, H. H.; El- Karachily, A. F.; Fattouh, Sh. and Abdel- Khalek, Z. (1995). Statistcal study of the annual catch from Lake Qarun as indication of its pollution. The fifth International Conference, Environmental Protection is a must, 417- 433.

Shalloof, K.A. Sh. (2009). Some observations on fisheries biology of Tilapia zillii (Gervais, 1848) and Solea vulgaris (Quensel, 1806) in Lake Qarun, Egypt. World J. Fish and Mar. Sci. 1 (1): 20-28, 


\section{Kariman A. Sh. Shalloof}

Shehata, S.M.A.; Ghanem, M.H.M. and Ragab A.M.M. (2017). Effect of Some Environmental Factors on the Food and Feeding Habits of the Cichlid Fish, Tilapia zillii, Inhabiting Lake Qarun, Egypt. Egypt. Acad. J. Biolog. Sci., 9(1): 55- 70.

Soliman, G.F. (1990). Observations on some Physical conditions of Lake Qarun, Regional Symp. Environ. Stud. (UNARC), Alexandra, Egypt, pp. 588-601.

Swielum, M.A. (1989). Some biological aspects on Mugil capito Cuv. In Lake Qarun. M. Sc. Thesis Fac. Sci. Zagazig Univ. 138 pp

Wimpenny, R. S. and H. Foauzi (1935). The breeding of the grey mullet, M. capito Cuv., in Lake Qarun, Egypt. Nature, London, 135 (3425): 1041

Wimpenny, R.S. (1936). The Ova and Larvae of Cuv., from lake Qarun, Egypt. Ann. Mag. Nat. Hist. Ser., 10: 405- 413

Zahran, M.A. (1973). Wadi El-Rayan: A natural water reservoir (Western Desert, Egypt). Bull. Soc. Geogr. d'Egypt., XLII-XLIV: 83-99. 